\title{
Pendidikan Kesehatan tentang Pre Eklamsi Penting untuk Pengetahuan Ibu Hamil dalam Persiapan Menghadapi Komplikasi
}

\author{
Winancy \\ Jurusan Kebidanan Poltekkes kemenkes Jakarta III \\ Email korespondensi: winancygunawan@gmail.com
}

\begin{abstract}
Article Info
\end{abstract}
ABSTRACT

Article history:

Submitted: 2019-02-22

Accepted: 2019-04-16

Published: 2019-04-22

Keywords:

Pre-eclampsia;

Health Education;

Multimedia;

Leaflets.
Preeclampsia is one of the direct causes of maternal death, the incidence of preeclampsia initially does not provide symptoms and signs, but at one time it can deteriorate rapidly, so it needs a series of examinations, detection, and identification of risk factors and controls so that it is possible to do complex primary prevention. This disease is closely related to the factors of age, parity and history of hypertension, so the alertness of pregnant women and their families in early detection of complications of pregnancy plays an important role. This study aims to determine the effect of health education about pre-eclampsia on knowledge, attitudes, and preparation for coping with labor complications in pregnant women in the health center of Tapos Depok sub-district in 2017. This study was a quasi-experimental study with a pre-test and posttest design. The sample in this study were pregnant women who examined their pregnancies at the Tapos Sub-District Health Center at the time of data collection as many as 60 respondents who were divided into two groups and taken by accidental sampling. Respondents were divided into 2 groups, namely those who were given health education with leaflet and multimedia media. Data analysis was done by univariate and bivariate with Wilcoxon and Mann Whitney tests. The results showed that there was an effect of health education about pre-eclampsia on the increase in knowledge and attitudes of pregnant women, but did not affect the preparation of pregnant women in preparation for complications of labor. Health education using multimedia is more able to increase respondents' knowledge and attitudes about preeclampsia compared to health education with leaflet media.

\section{PENDAHULUAN}

Kesehatan ibu dan anak menjadi isue penting yang dihadapi Indonesia dalam dekade ini, angka kematian ibu mengalami peningkatan di tahun 2012 dibandingkan tahun 2007, yaitu 359/100.000 kelahiran hidup. Penyebab langsung kematian ibu di Indonesia adalah perdarahan, hipertensi dalam kehamilan atau pre eklampsi/eklamsi, abortus, infeksi, partus lama/macet dan penyebab lain yaitu penyakit penyerta yang diderita ibu saat hamil meliputi penyakit menular seperti malaria, diabetes melitus, gangguan jiwa, ataupun kekurangan gizi. ${ }^{1,2}$ Kematian ibu yang disebabkan karena preeklamsi mengalami kenaikan yang sangat signifikan yaitu 21,5\% pada tahun 2010 naik menjadi $27,1 \%$ pada tahun $2013 .{ }^{3}$ Kejadian pre eklamsi/eklamsi paling banyak terjadi pada ibu yang berusia $20-35$ tahun (63\%), dan $50 \%$ terjadi pada multipara. ${ }^{4}$ Pre Eklamsi merupakan salah satu penyebab langsung kematian ibu, kejadian pre eklamsi pada awalnya tidak memberikan gejala dan tanda, namun pada suatu ketika dapat memburuk dengan cepat, sehingga butuh serangkaian pemeriksaan, deteksi, dan 
identifikasi faktor risiko serta mengontrolnya sehingga memungkinkan dilakukan pencegahan primer yang kompleks. Penyakit ini berkaitan erat dengan faktor umur, paritas dan riwayat penyakit hipertensi, sehingga kewaspadaan ibu hamil dan keluarganya dalam deteksi dini komplikasi kehamilan sangat berperan penting. Hasil penelitian Devi Kurniasari pada tahun 2014 menunjukkan data bahwa faktor faktor yang berpengaruh terhadap kejadian pre ekalmsi (PER) yaitu usia dan paritas, hasil yang sama juga diungkapkan oleh Rohaya dan Suprida dalam penelitian tentang hubungan usia, umur kehamilan, dan paritas dengan kejadian PER pada tahun 2009. Riwayat pre eklamsi mempunyai risiko 15,506 kali dan paritas mempunyai risiko 4,751 kali untuk menjadi penyebab terjadinya PER pada ibu hamil. ${ }^{5-7}$

Bidan dapat berperan dalam pelayanan kesehatan primer, sekunder, tersier dan fungsi promotif untuk menjaga kesehatan masyarakat. Sistem pelayanan kesehatan yang baik dapat memfasillitasi bidan untuk mendukung perempuan dalam menghadapi kehamilan yang tidak diinginkan, menyediakan pendampingan sepanjang kehamilan dan kelahiran, serta menyelamatkan nyawa bayi yang lahir sebelum waktunya. ${ }^{8}$ Kegiatan komunikasi, informasi dan edukasi (KIE) melalui penyuluhan tentang kesehatan ibu kepada masyarakat khususnya kepada ibu hamil, suami dan mertua dapat memanfaatkan media cetak dan elektronik untuk kampanye tentang kesehatan ibu, pemantauan kesehatan ibu hamil dan persiapan persalinan dapat dilaksanakan secara efektif dan efisien melalui pemberdayaan masyarakat, kemitraan petugas kesehatan dengan masyarakat serta mewujudkan kesadaran, kemandirian keluarga untuk menjaga kesehatan ibu dan anak. ${ }^{1}$ Penelitian tentang pengaruh penyuluhan terhadap pengetahuan masyarakat Tembalang tentang Leptospirosis menunjukkan hasil bahwa penyuluhan sangat efektif meningkatkan pengetahuan masyarakat tentang leptospirosis dan direkomendasikan sebagai salah satu metode promosi. $^{9}$

Pre eklamsi merupakan salah satu penyebab langsung kematian ibu, namun belum diketahui secara pasti penyebab dari penyakit ini. Kewaspadaan ibu hamil dan keluarga tentang tanda dan gejala pre eklamsi sangat penting bagi pencegahan komplikasi kehamilan yang dapat mengancam nyawa ibu dan janin, kesadaran ini akan lebih baik jika didukung oleh pengetahuan yang cukup tentang pre eklamsi sehingga akan mempengaruhi sikap ibu dan keluarga untuk memiliki persiapan yang maksimal dalam menghadapi keadaan gawat darurat kehamilan, persalinan, dan nifas serta mendukung terlaksananya Program Perencanaan Persalinan dan Pencegahan Komplikasi (P4K) yang merupakan program percepatan penurunan angka kematian ibu di Indonesia. ${ }^{10}$ Tujuan penelitian yaitu untuk mengetahui pengaruh pendidikan kesehatan dengan multimedia dan leaflet serta dibandingkan media manakah yang lebih memberikan pengaruh pada peningkatan pengetahuan dan sikap responden tentang pre eklamsi. Pengetahuan dan sikap responden tentang pre eklamsi penting sebagai dasar persiapan yang dilakukan responden dalam menghadapi komplikasi persalinan sebagai akibat dari pre eklamsi.

\section{METODE PENELITIAN}

Penelitian ini merupakan penelitian Quasi eksperimen dengan pre test dan posttest design. Penelitian dilakukan di Puskesmas Kecamatan Tapos Kota Depok. Penelitian dilaksanakan pada bulan Maret - Agustus 2017. Data dikumpulkan menggunakan kuesioner kepada ibu hamil. Tingkat pengetahuan dan sikap responden dinilai sebelum dan setelah proses pendidikan Kesehatan. Pendidikan kesehatan 
diberikan dengan menggunakan multi media pada kelompok perlakuan dan menggunakan media leaflet pada kelompok kontrol.

Populasi dalam penelitian ini yaitu semua ibu hamil yang datang memeriksakan kehamilannya di Puskesmas kecamatan Tapos Depok. Sampel penelitian yaitu sebanyak 60 ibu hamil (30 responden untuk masing masing kelompok).Teknik pengambilan sampel dilakukan secara non random sampling sesuai dengan kriteria inklusi dan bersifat accidental sampling. Pengambilan data dilakukan setelah peneliti memberikan penjelasan terlebih dahulu kepada calon responden meliputi maksud dan tujuan, serta manfaat penelitian. Kuesioner diberikan kepada responden setelah menandatangani Informed Consent.

Analisis Uji statistik yang digunakan untuk mengetahui perbedaan nilai pengetahuan dan sikap antara kelompok kontrol dan kelompok perlakuan yaitu uji Mann-Whitney karena data tidak berdistribusi normal. Analisis untuk mengetahui pengaruh pendidikan kesehatan terhadap tingkat pengetahuan dan sikap sebelum dan setelah proses pendidikan kesehatan dalam satu kelompok menggunakan uji Wilcoxon karena data tidak berdistribusi normal.

\section{HASIL PENELITIAN}

Hasil penelitian akan menyajikan informasi hasil penghitungan data secara statistic dan penjelasannya. Hasil penelitian yang disajikan meliputi gambaran karakteristik responden berdasarkan umur, pendidikan, pekerjaan, riwayat pre eklamsi pada orang tua, dan jumlah kehamilan yang sudah dialami. Data ini juga menunjukkan pengaruh pendidikan kesehatan dengan multimedia atau media leflet pada dua kelompok serta membandingkan pengaruh dua media terhadap peningkatan pengetahuan, sikap responden tentang pre eklamsi.

Tabel 1. Distribusi frekuensi Karakteristik Responden pada kelompok Pendidikan Kesehatan dengan Multimedia dan Media Leaflet

\begin{tabular}{|c|c|c|}
\hline Karakteristik Responden & Frekuensi & Presentase(\%) \\
\hline \multicolumn{3}{|l|}{ Umur } \\
\hline$<20$ Tahun $\&>35$ thn & 23 & 38,3 \\
\hline 20-35 Tahun & 37 & 61,7 \\
\hline \multicolumn{3}{|l|}{ Pendidikan } \\
\hline$<$ SMA/sederajat & 43 & 71,1 \\
\hline 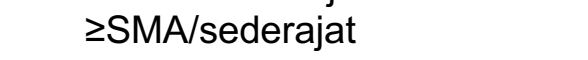 & 17 & 28,3 \\
\hline \multicolumn{3}{|l|}{ Pekerjaan } \\
\hline Bekerja & 3 & 5 \\
\hline Tidak Bekerja & 57 & 95 \\
\hline \multicolumn{3}{|l|}{ Riwayat pre eklamsi } \\
\hline Ya & 4 & 6,7 \\
\hline Tidak & 56 & 66,7 \\
\hline \multicolumn{3}{|l|}{ KeturunanPre eklamsi } \\
\hline Ya & 4 & 6,7 \\
\hline Tidak & 56 & 93,3 \\
\hline \multicolumn{3}{|l|}{ Jumlah kehamilan istri } \\
\hline Primigravida & 20 & 33,3 \\
\hline Multigravida & 40 & 66,7 \\
\hline
\end{tabular}


Pada tabel 1 dapat terlihat bahwa sebagian besar responden berada pada rentang umur $20-35$ tahun sebesar $61,7 \%$. Tingkat pendidikan responden lebih besar di level pendidikan rendah yaitu sebesar $71,1 \%$, sebagian besar responden tidak bekerja dan hanya ada $5 \%$ responden yang bekerja. Riwayat pre eklamsi dan adanya keturunan pre eklamsi tidak dimiliki oleh sebagian besar responden dan hanaya 6,7\% yang memiliki riwayat dan keturunan pre eklamsi. Lebih dari setengah jumlah responden sedang mengandung anak yang ke dua atau lebih yaitu sebesar $66,7 \%$.

Tabel 2. Perbedaan tingkat pengetahuan, sikap dan persiapan menghadapi komplikasi persalinan pada kelompok multimedia dan leaflet sebelum dan setelah pendidikan kesehatan

\begin{tabular}{|c|c|c|c|c|c|}
\hline \multirow[t]{2}{*}{ Variabel } & \multirow[t]{2}{*}{ Perbedaan } & \multicolumn{2}{|c|}{$\begin{array}{l}\text { Multi Media } \\
\quad(n=30)\end{array}$} & \multicolumn{2}{|c|}{$\begin{array}{l}\text { Leaflet } \\
(n=30)\end{array}$} \\
\hline & & Mean & Nilai $p^{*}$ & & Nilai $p^{*}$ \\
\hline \multirow[t]{2}{*}{ Pengetahuan } & Pretest & 3,25 & $<0,001$ & 3,00 & $<0,001$ \\
\hline & Posttest & 9,68 & & 9,53 & \\
\hline \multirow[t]{2}{*}{ Sikap } & Pretest & 22,25 & $<0,001$ & 22,68 & $<0,001$ \\
\hline & Posttest & 30,76 & & 29,00 & \\
\hline \multirow[t]{2}{*}{ Persiapan P4K } & Pretest & 6,07 & $<0,001$ & 6,05 & $<0,001$ \\
\hline & Posttest & 7,39 & & 7,38 & \\
\hline
\end{tabular}

Ket : ${ }^{*}$ ) Nilai $p$ dihitung dengan uji Wilcoxon

Pada tabel 2 dapat diketahui bahwa tingkat pengetahuan responden sebelum diberikan pendidikan kesehatan dan setelah meningkat secara bermakna, sikap responden juga mengalami peningkatan yang sangat bermakna serta persiapan responden dalam menghadapi komplikasi persalinan mengalami peningkatan sebelum dan setelah pendidikan kesehatan. Peningkatan terhadap pengetahuan, sikap, dan persiapan sangat bermakna secara statistik dibuktikan dengan nilai pvalue $<0,001$

Tabel 3. Perbedaan tingkat pengetahuan, pada kelompok pendidikan kesehatan dengan multimedia dan media leaflet

\begin{tabular}{lccc}
\hline Variabel Pengetahuan & \multicolumn{2}{c}{ Kelompok } & Nilai $\mathbf{~}^{*}$ \\
\cline { 2 - 3 } & $\begin{array}{c}\text { Multimedia } \\
(\mathbf{n}=\mathbf{3 0})\end{array}$ & $\begin{array}{c}\text { Leaflet } \\
(\mathbf{n}=\mathbf{3 0})\end{array}$ & 0,127 \\
\hline $\begin{array}{c}\text { Pretest } \\
\text { Mean }\end{array}$ & 33,9 & 27,1 & 0,038 \\
\hline $\begin{array}{c}\text { Posttest } \\
\text { Mean }\end{array}$ & 34,2 & 28,8 & \\
\hline Ket: $\left.{ }^{*}\right)$ Nilai p dihitung berdasarkan uji Mann-Whitney
\end{tabular}

Berdasarkan tabel 3 tergambar bahwa nilai rerata (mean) tingkat pengetahuan responden sebelum diberikan pendidikan kesehatan tidak berbedah antara kelompok multimedia dan leaflet yaitu 33,9 dan 27,1 dengan hasil uji statistik $p>0,05 \quad(p=0,127)$ yang artinya tingkat pengetahuan responden sebelum dan setelah proses pendidikan 
kesehatan pada dua kelompok tidak berbeda. Nilai mean pada posttest meningkat secara bermakna, skor mean pada kelompok multimedia meningkat dari 33,9 menjadi 34,2 dan pada kelompok media leaflet meningkat dari 27,1 menjadi 28,8 dan peningakatan ini bermakna secara statistik dengan nilai $p<0,05(P=0,038)$.

Tabel 4. Perbedaan sikap pada kelompok pendidikan kesehatan dengan multimedia dan media leaflet

\begin{tabular}{lccc}
\hline Variabel Sikap & \multicolumn{2}{c}{ Kelompok } & Nilai $\mathbf{p}^{*}$ \\
\cline { 2 - 3 } & $\begin{array}{c}\text { Multimedia } \\
(\mathbf{n}=\mathbf{3 0})\end{array}$ & $\begin{array}{c}\text { Leaflet } \\
(\mathbf{n}=\mathbf{3 0})\end{array}$ & 0,289 \\
\hline $\begin{array}{l}\text { Pretest } \\
\text { Mean }\end{array}$ & 32,9 & 28,1 & 0,013 \\
\hline $\begin{array}{l}\text { Posttest 1 } \\
\text { Mean }\end{array}$ & 36,1 & 28,9 & \\
\hline \multicolumn{2}{l}{ Ket: $\left.{ }^{*}\right)$ Nilai p dihitung berdasarkan uji Mann-Whitney }
\end{tabular}

Berbedaan sikap responden pada kelompok intervensi dan kontrol sebelum dan setelah pendidikan kesehatan dapat dilihat dalam tabel 4.4 di atas. Pada tabel tersebut dapat diketahui bahwa nilai mean sikap responden pada kedua kelompok tidak berbeda bermakna secara statistik dengan nilai $p>0,05(P=0,289)$, tetapi nilai mean sikap responden pada kedua kelompok setelah proses pendidikan menjadi berbeda secara bermakna, yaitu nilai mean 36,1 pada kelompok multimedia dan 28,9 pada kelompok media leaflet. Perbedaan nilai ini bermakna secara statistik dengan hasil nilai $p<0,05(p=0,013)$

Tabel 5. Perbedaan persiapan menghadapi komplikasi persalinan pada kelompok pendidikan kesehatan dengan multimedia dan media leaflet

\begin{tabular}{lccc}
\hline Variabel Persiapan P4K & \multicolumn{2}{c}{ Kelompok } & Nilai $\mathbf{p}^{*}$ \\
\cline { 2 - 3 } & $\begin{array}{c}\text { Multimedia } \\
(\mathbf{n}=\mathbf{3 0})\end{array}$ & $\begin{array}{c}\text { Leaflet } \\
(\mathbf{n}=\mathbf{3 0})\end{array}$ & 0,964 \\
\hline $\begin{array}{c}\text { Pretest } \\
\text { Mean }\end{array}$ & 30,6 & 30,4 & 0,868 \\
\hline $\begin{array}{c}\text { Posttest } \\
\text { Mean }\end{array}$ & 30,8 & 30,4 & 0,4 \\
\hline
\end{tabular}

Ket: *) Nilai p dihitung berdasarkan uji Mann-Whitney

Pada tabel 5 dapat diketahui bahwa persiapan reponden menghadapi komplikasi persalinan tidak berbeda pada kedua kelompok sebelum diberikan pendidikan kesehatan, hal ini dapat diketahui dari nilai mean kelompok multimedia 30,6 dan kelompok media leaflet 30,4. Nilai mean yang hampir sama menunjukkan tidak ada perbedaan diantara kedua kelompok dan hal ini dibuktikan dengan hasil uji statistik $p=0,964$. Nilai mean setelah pendidikan kesehatan hanya mengalami sedikit peningkatan pada kelompok multimedia yaitu 0,2 poin dan pada kelompok media leaflet tidak ada perubahan, hal ini menyebabkan tidak bermaknanya berbedaan kedua kelompk tersebut secara statistik dengan nilai $p=0,869$

Berdasarkan pengujian secara statistik dan nilai mean yang didapat maka dapat disimpulkan bahwa pendidikan kesehatan dengan menggunakan multimedia lebih 
dapat meningkatkan pengetahuan dan sikap responden tentang pre eklamsi dibandingkan dengan pendidikan kesehatan dengan media leaflet.

\section{PEMBAHASAN}

Berdasarkan uji statistik dengan wilcoxon dapat diketahui bahwa nilai $\mathrm{p}$ dari uji statistik sebelum dan setelah proses pendidikan kesehatan tentang pre eklamsi mengalami perubahan/peningkatan yang sangat bermakna yaitu $<0,05(p=0,001)$. Pendidikan kesehatan merupakan cara untuk mempermudah perubahan perilaku secara sukarela dalam meningkatkan kesehatan. Pendidikan kesehatan merupakan bentuk intervensi terhadap faktor sosial, budaya, politik, dan ekonomi yang mempengaruhi perilaku seseorang. ${ }^{11}$ Pendidikan kesehatan mengupayakan masyarakat untuk mengetahui dan menyadari bagaimana berperilaku hidup sehat, melalui pendidikan kesehatan masyarakat memiliki pengetahun bagaimana cara hidup sehat.

Keberhasilan pendidikan kesehatan dipengaruhi oleh banyak faktor diantaranya media pendidikan. ${ }^{11}$ Pengetahuan merupakan semua yang diketaui tentang suatu objek tertentu atau ilmu, melalui pengetahuan yang dimiliki responden tentang pre eklamsi diharapkan dapat merubah sikap responden tentang pre eklamsi ke arah postif. ${ }^{12,13}$ Pengetahuan yang baik tentang pre eklamsi akan membantu responden untuk mewaspadai kejadian pre eklamsi pada kehamilannya, menghindari faktor penyebab pre eklamsi dan mencari pertolongan yang tepat jika mengalami pre eklamsi serta memiliki persiapan yang baik dalam menghadapi komplikasi yang ditimbulkan.

Penelitian Devi Kurniasih pada tahun 2014 menunjukkan hasil bahwa faktor yang mempengaruhi pre eklasmi yaitu umur ibu dan jumlah paritas, hasil yang sama juga ditunjukkan oleh penelitian Rohaya dan Suprida yang meneliti pada tahun 2009 tentang hubungan umur dan paritas dengan kejadian pre eklamsi. ${ }^{5,7}$ Pendidikan kesehatan merupakan upaya memberdayakan masyarakat dalam memiliki kesadaran dan kemandirian keluarga untuk menjaga kesehatan ibu dan anak, keberhasilan pendidikan kesehatan sangat dipegaruhi oleh media yang digunakan. ${ }^{1}$

Pendidikan kesehatan dengan media yang melibatkan banyak indera akan lebih dapat diserap oleh responden/peserta karena pancaindera yang paling besar berperan dalam menyalurkan pengetahuan ke otak yaitu mata $(75 \%-87 \%)$, dan $13 \%-25 \%$ disalurkan melalui pancaindera yang lain. ${ }^{14}$ Penelitian Pepi dan Rinela tentang efektifitas pendidikan kesehatan melalui multimedia dan tatap muka menyatakan bahwa pendidikan kesehatan dengan multimedia dapat meningkatkan nilai rerata pengetahuan responden sebesar 3,8 poin ini lebih tinggi dibandingkan denga tatap muka yang hanya 1,2. ${ }^{15}$ Hasil penelitian yang dilakukan oleh Susanti Fajar tahun 2011 menunjukan bahwa pendidikan kesehatan dengan multimedia 16,41\% lebih efektif dalam meningkatkan pengetahuan lanjut usia tentang pencegahan penyakit asam urat dibandingkan dengan media leaflet di Kelurahan Tugu Depok. ${ }^{16}$

Sikap merupakan faktor predisposisi bagi seseorang untuk berperilaku. Sikap merupakan kesediaan seseorang dalam merespon suatu rangsangan positif atau negatif. ${ }^{12,13}$ Sikap ibu hamil tentang pre eklamsi merupakan kesediaan responden dalam mengenal tentang pre eklamsi dan mewaspadai kejadian pre eklamsi dalam kehamilannya, termasuk tentang faktor-faktor yang mempengaruhi, penyebab, akibat, tanda dan gejala serta tindakan penanganan. Sikap dapat terbentuk jika seseorang memiliki pengetahuan tentang suatu masalah, sikap yang positif ditunjang oleh pengetahuan yang cukup terhadap objek tertentu. 
Penelitian Pepi dan Rinela tentang efektifitas pendidikan kesehatan melalui multimedia dan tatap muka menyatakan bahwa pendidikan kesehatan dengan multimedia dan tatap muka dapat meningkatkan nilai rerata sikap responden dari 63,1 saat pretest menjadi 66,83 pada posttest dengan selisi 3,73 point, peningkatan ini bermakna secara statistik. ${ }^{15}$ Penelitian yang dilakukan oleh Hardiningsih terhadap siswa kelas XI tentang pencegahan HIVIAIDS dengan media leaflet dan ceramah menunjukkan hasil bahwa pendidikan kesehatan dengan leeflet dapat meningkatkan rerata skor sikap remaja dari 57,71 menjadi 70,74 dengan kenaikan skor rerata 13,03. Penelitian ini juga mengungkapkan bahwa penggunaan leaflet pada pendidikan kesehatan meningkatkan sikap responden lebih baik dibandingkan dengan ceramah. ${ }^{17}$

Hasil penelitian yang dilakukan oleh Susanti Fajar tahun 2011 menunjukan bahwa pendidikan kesehatan dengan multimedia $16,41 \%$ lebih efektif dalam meningkatkan pengetahuan lanjut usia tentang pencegahan penyakit asam urat dibandingkan dengan media leaflet di Kelurahan Tugu Depok. ${ }^{16}$ Persiapan menghadapi komplikasi persalinan dalam penelitian ini yaitu persiapan ibu dalam memenuhi semua kebutuhan persalinan sesuai yang terdapat dalam program perencanaan persalinan dan pencegahan komplikasi (P4K) yang meliputi rencana tempat persalinan, penolong persalinan, pendamping persalinan, calon donor darah, alat transportasi, biaya persalinan, dan tempat rujukan jika diperlukan. ${ }^{10}$

Persiapan menghadapi komplikasi persalinan dalam penelitian ini yaitu perilaku tertutup dari responden berupa respon berupa perhatian, persepsi, pengetahuan dan kesadaran terhadap pemenuhan P4K. ${ }^{11}$ Penelitian ini memberikan hasil bahwa pendidikan kesehatan tidak mempengaruhi perilaku responden terhadap persiapan yang dilakukan, skor rerata dari hasil analisis data menunjukkan tidak berbeda antar sebelum dan setelah proses pendidikan kesehatan. Skor rerata ini tidak berbeda bermakna dengan nilai $p>0,05$ pada kelompok multimedia maupun kelompok leaflet, hal ini dapat disebabkan bahwa perencanaan dan persiapan P4K merupakan program yang ditetapkan oleh pemerintah bagi setiap ibu hamil yang datang memeriksakan kehamilannya diinstansi kesehatan sehingga semua ibu hamil diharuskan memiliki isian terhadap point pertanyaan dari program P4K baik ibu hamil mengetahu atau tidak tentang pre eklamsi atau tanda kegawatdaruratan lainnya.

Penelitian yang dilakukan Willa Susiani tahun 2012 tentang pengaruh penyuluhan kesehatan tentang $\mathrm{P} 4 \mathrm{~K}$ terhadap pemilihan penolong persalinan menunjukkan hasil yang bermakna yaitu bahwa ibu hamil yang diberikan penyuluhan tentang P4K memiliki peluang 9,3 kali untuk memilih tenaga kesehatan sebagai penolong persalinan. ${ }^{18}$

\section{Pengaruh Pendidikan kesehatan dengan multimedia dan media leaflet terhadap peningkatan pengetahuan, sikap, dan persiapan menghadapi komplikasi persalinan (P4K) tentang pre eklamsi}

Pendidikan kesehatan memberikan pengaruh terhadap peningkatan pengetahuan dan sikap responden tentang pre eklamsi, responden pada kelompok multimedia dan media leaflet memiliki skor rerata yang berbeda secara bermakna dengan nilai $p<0,05$ tetapi tidak mengalami perbedaan yang bermakna pada persiapan menghadapi komplikasi persalianan atau program P4K. Hasil penelitian ini menunjukkan skor rerata pengetahuan dan sikap pada kelompok multimedia lebih tinggi dibandingkan dengan kelompok media leaflet, sehingga dapat disimpulkan bahwa pengaruh pendidikan kesehatan dengan multimedia lebih efektif meningkatklan pengetahuan dan sikap responden tentang pre eklamsi dibaningkan dengan media leflet. 
Penelitian Pepi dan Rinela tentang efektifitas pendidikan kesehatan melalui multimedia dan tatap muka pada tahun 2017 menyatakan bahwa pendidikan kesehatan dengan multimedia dapat meningkatkan nilai rerata pengetahuan responden sebesar 3,8 poin ini lebih tinggi dibandingkan denga tatap muka yang hanya 1,2. ${ }^{15}$ Hasil penelitian yang dilakukan oleh Susanti Fajar tahun 2011 menunjukan bahwa pendidikan kesehatan dengan multimedia $16,41 \%$ lebih efektif dalam meningkatkan pengetahuan lanjut usia tentang pencegahan penyakit asam urat dibandingkan dengan media leaflet di Kelurahan Tugu Depok. ${ }^{16}$

\section{SIMPULAN DAN SARAN}

Pendidikan kesehatan dengan multimedia dan media leaflet memberikan pengaruh yang bermakna terhadap peningkatan pengetahuan dan sikap responden dengan nilai $<0,001$. Pendidikan kesehatan dengan multimedia dan media leaflet tidak memberi pengaruh secara bermakna pada persiapan responden menghadapi komplikasi persalinan. Pendidikan kesehatan dengan multimedia lebih efektif dalam meningkatkan pengetahuan dan sikap responden tentang pre eklamsi. Penelitian ini dapat dikembangkan dengan menggunakan metode penelitian yang lebih lengkap, responden yang lebih banyak dan melibatkan keluarga ibu hamil serta lokasi penelitian yang lebih luas lagi sehingga dapat memberi hasil yang lengkap tentang gambaran pengetahuan dan sikap ibu hamil, keluarga tentang pre eklamsi.

\section{UCAPAN TERIMA KASIH}

Ucapan terima kasih kepada Pemerintah Indonesia khususnya Kementerian Kesehatan dan Poltekkes Kemenkes Jakarta III yang telah memberi kesempatan pada penulis untuk melakukan penelitian setiap tahun, kepada keluarga dan teman-teman yang senantiasa memberi dukungan penuh serta tim pembimbing yang telah sabar dan penuh keikhlasan membimbing penulis selama penyusunan laporan penelitian. Terima kasih juga kepada pemerintah Kota Depok yang telah memberi izin untuk melakukan penelitian, Puskesmas Kecamatan Tapos sebagai lokasi penelitian serta ibu hamil di lokasi penelitian yang berpartisipasi dalam kegiatan penelitian ini.

\section{DAFTAR PUSTAKA}

1. Kementerian Kesehatan R.I. Laporan Hasil Riset Kesehatan Dasar (Riskesdas) Indonesia tahun 2007. Jakarta: Kementerian Kesehatan R.I.; 2008.

2. Badan Kependudukan dan Keluarga Berencana Nasional, Badan Pusat Statistik, Kementerian Kesehatan R.I., ICF International. Survei Demografi dan Kesehatan Indonesia 2012. Jakarta: Badan Kependudukan dan Keluarga Berencana Nasional; 2013.

3. Kementerian Kesehatan R.I. Profil Kesehatan Indonesia tahun 2014. Jakarta: Kementerian Kesehatan R.I.; 2015.

4. Wardani W. Gambaran Beberapa Faktor Risiko yang Mempengaruhi Preeklamsia Berat pada Ibu Hamil di RSUD Prof. dr. Margono Soekarjo Purwokerto Tahun 2010. Akademi Kebidanan YLPP Purwokerto.; 2012.

5. Kurniasari D, Arifandini F. Hubungan Usia, Paritas, dan Diabetes Mellitus pada Kehamilan Dengan Kejadian Preeklamsia Pada Ibu Hamil di Wilayah Kerja Puskesmas Rumbia Kabupaten Lampung Tengah Tahun 2014. J Kesehat Holistik [Internet]. 2015;9(3):142-50. Tersedia pada: http://ejurnalmalahayati.ac.id/index.php/holistik/article/view/232/171

6. Rozikhan R. Faktor -Faktor Risiko Terjadinya Preeklamsi Berat di Rumah Sakit Dr. Soewondo Kendal [Internet]. Universitas Diponegoro; 2007. Tersedia pada: 
http://eprints.undip.ac.id/4918/

7. Rohaya, Suprida. Hubungan Umur, Usia Kehamilan dan Gravida dengan Kejadian Pre - eklampsi pada Ibu Bersalin di Instalasi Rawat Inap Kebidanan dan Penyakit Kandungan RSUP Dr. Moh. Hoesin Palembang Tahun 2009. J Kesehat Poltekkes Padang [Internet]. 2010;12(2):1-11. Tersedia pada: https://jurnal.poltekkespalembang.ac.id/index.php/JPP/article/view/133

8. Gloria. Bidan Berperan dalam Pencapaian Target SDGs [Internet]. Universitas Gadjah Mada. 2016. Tersedia pada: https://www.ugm.ac.id/id/newsPdf/13022bidan.berperan.dalam.pencapaian.target.sdgs

9. Wijayanti T, Isnani T, Kesuma AP. Pengaruh Penyuluhan (Ceramah dengan Power Point) terhadap Pengetahuan tentang Leptospirosis di Kecamatan Tembalang, Kota Semarang Jawa Tengah. Balaba J Litbang Pengendali Penyakit Bersumber Binatang Banjarnegara. 2016;12(1):39-46.

10. Kementerian Kesehatan R.I. Metode dan Media Promosi Kesehatan. Jakarta: Pusat Promosi Kesehatan Kementerian Kesehatan R.I.; 2008.

11. Notoatmodjo S. Promosi Kesehatan; Teori dan Aplikasinya. Jakarta: Rineka Cipta; 2010.

12. Notoatmodjo S. Promosi Kesehatan dan Perilaku Kesehatan. Jakarta: Rineka Cipta; 2012.

13. Azwar S. Sikap Manusia Teori jan Pengukurannya. Yogjakarta: Pustaka Pelajar; 2008.

14. Maulana HDJ. Promosi Kesehatan. Jakarta: EGC; 2009.

15. Hapitria P, Padmawati R. Efentivitas Pendidikan Kesehatan Melalui Multimedia dan Tatap Muka terhadap Pengetahuan dan Sikap Ibu Hamil tentang ASI dan Menyusi. J Care. 2017;5(2):156-67.

16. Susanti F. Efektifitas Multimedia Interaktif sebagai Media Pendidikan Kesehatan terhadap Peningkatan Pengetahuan Lanjut Usia tentang Pencegahan Penyakit Asam Urat di Kel. Depok [Internet]. Universitas Indonesia; 2011. Tersedia pada: http://www.lontar.ui.ac.id/file?file=pdf/abstrak-20280889.pdf

17. Hardiningsih. Perbedaan Pendidikan Kesehatan Dengan Ceramah Dan Leaflet Terhadap Pengetahuan Dan Sikap Dalam Rangka Pencegahan Human Immunodeficiency Virus/acquired Immune Deficiency Syndrome (HIVIAIDS) pada Siswa Kelas XI Sekolah Menengah Atas Negeri 4 Surakarta. Vol. 3, perpustakaan.uns.ac.id. Universitas Sebelas Maret; 2012.

18. Dewi Susiani W. Pengaruh Penyuluhan Kesehatan tentang Program Perencanaan Persalinan dan Pencegahan Komplikasi (P4K) terhadap Pemilihan Pertolongan Persalinan oleh Ibu Hamil Di Desa Karangpawitan Kabupaten Garut Provinsi Jawa Barat. Universitas Indonesia; 2012. 